\title{
Study on Teaching Reform of the Course Named Introduction to Civil Engineering
}

\author{
Lin Longbin \\ Department of Civil Engineering \\ Xiamen University Tan Kah Kee College \\ Fujian, Zhangzhou, PR of China, 363105
}

\author{
Feng Zhengwei* \\ Department of Civil Engineering \\ Xiamen University Tan Kah Kee College \\ Fujian, Zhangzhou, PR of China, 363105 \\ E-mail: 21584743@qq.com
}

\begin{abstract}
With the decrease of class hours and the change of distribution ratio, it becomes difficult to complete the required course content scheduled by the old teaching syllabus. Moreover, the teaching content can't match with the composition of teaching hours. Combined with the experience achieved during the construction of provincial excellent course and teaching in the past years, some reform measures are put forward by rearranging the content of the old teaching syllabus. Special topic teaching mode is adopted, and a number of new teaching methods and means are tried, and so that the teaching mode and class structure match each other, and so it's more conducive to implementation of teaching. Through the teaching reform, good teaching effect has been achieved. Not only the teaching objective of the course has been successfully completed, but also the practice and exploration of the training mode of applicationoriented talents has been actively promoted.
\end{abstract}

Keywords-Introduction to Civil Engineering; teaching reform; course teaching; teaching methods

\section{INTRODUCTION}

A significant modification to the personnel training program of Civil Engineering Majors in the Department of Civil Engineering of the Tan Kah Kee College of Xiamen University was done in 2015 in order to make the civil engineering program meet the need for practice-orientated undergraduate education. This modification was done by referring to personnel training programs of civil engineering from five similar domestic universities and five overseas universities, and seeking the views from five domestic enterprises and institutions. After the modification, the credits of course - "Introduction to Civil Engineering" were changed from 2 credits to 1 credit, and 34 theoretical class hours were changed to 16 theoretical class hours plus 12 practical class hours. In accordance with the experience of the course in the construction of provincial excellent courses, and the author's many years of teaching experience, a brief discussion was presented regarding the teaching reform for the purpose of ensuring the teaching effectiveness considering the course hour reduction and structural changes.

\section{The Positioning OF Courses IN THE MAJOR TrAining GOALS AND THE GOALS OF COURSES}

"Introduction to Civil Engineering “ was an important and

This work was supported by the education science "13th Five-year Plan" key topic of Fujian Province of China (No. FJJKCGZ16-069). compulsory undergraduate professional course of Civil Engineering Major in universities, as well as one of important basic courses of environmental science, architecture and engineering management major. The characteristics of this course included broad knowledge scopes, intensive enlightenment and so on. With the development of civil engineering industry, the contents of the "Introduction to Civil Engineering " should also pay more attention to the latest achievements of the industry development and absorb new contents continuously.

The course was the first professional compulsory course for the students of civil engineering major after they entered the college; it was not only an introductory course, but also a basic course. The focus of the course was to describe the importance of civil engineering major and the areas it covered, introduce the latest technological achievements and information in China and overseas countries, and look forward to the future of civil engineering major. The main studying task was to understand the industry segmentation of civil engineering, to develop the studying interest to the civil engineering major, to establish a solid foundation for the further studying of the professional courses of the civil engineering major and independent study. Through the studying, students would be able to fully understand the contents and developments of civil engineering involved, learn the basic professional knowledge preliminarily, provide them with clear and logical basic concepts and methods of engineering major studying, create professional ideas and methods to make them generate strong aspiration to the knowledge accordingly, build a dedication belief to their civil engineering career to make them study consciously and lively.

\section{REFORM OF TEACHING CONTENTS}

The credits of the course were changed from 2 credits corresponding to 34 theoretical class hours to 1 credit corresponding to 16 theoretical class hours and 12 practical class hours. Theoretical class hours were reduced by 18 hours, but 12 practical class hours were newly added. After the change of the class hours, the original teaching contents had to be adjusted to adapt to the change. The main differences before and after the course change are shown in table 1 . The design of teaching content change is as follows: (1) The modified teaching content had to reflect the courses positioning in the major training goals and the goals of courses; 
(2) The teaching content should highlight the needs of personnel training of civil engineering major; (3) The amount of teaching contents should meet the demand of the new class hours, as well as 12 practical teaching class hours, and achieve an effective engagement between theory and practical teaching.

TABLE I. THE MAIN DIFFERENCES BEFORE AND AFTER THE COURSE CHANGE

\begin{tabular}{|c|c|c|c|c|}
\hline Items & Credit & $\begin{array}{c}\text { Theoretical } \\
\text { class hours }\end{array}$ & $\begin{array}{c}\text { Practical } \\
\text { class hours }\end{array}$ & $\begin{array}{c}\text { Teaching content } \\
\text { organization }\end{array}$ \\
\hline $\begin{array}{c}\text { before } \\
\text { change }\end{array}$ & 2 & 34 & 0 & $\begin{array}{c}\text { In the form of } \\
\text { chapters }\end{array}$ \\
\hline $\begin{array}{c}\text { after } \\
\text { change }\end{array}$ & 1 & 16 & 12 & $\begin{array}{c}\text { In the form of } \\
\text { special topics }\end{array}$ \\
\hline
\end{tabular}

There were a lot of original teaching contents, which included: the missions of the courses and studying suggestions, civil engineering materials, basic engineering, constructional engineering, traffic and civil engineering, bridge engineering, port engineering, underground engineering, water conservancy and hydropower engineering, water supply and drainage engineering, civil engineering construction, construction project management, prevention and mitigation of civil engineering disasters, applications of digital technology in civil engineering and so on. The above contents mainly correspond to the teaching content of 34 theoretical class hours.

The modified teaching contents were divided into several special topics, the contents were more refined so that the personnel training characteristics of civil engineering major could be highlighted and the practical teaching content could be met. The contents of main topics were as follows: Introduction and civil engineering materials topics; housing construction topics; road and bridge topics; introduction of other types of engineering. And the original contents, included port engineering, underground engineering, water conservancy and hydropower engineering, water supply and drainage engineering, civil engineering construction, construction project management, prevention and mitigation of civil engineering disaster, applications of digital technology in civil engineering have been cut short or briefed, part of the contents had been introduced briefly in some other types of engineering.

The contents which concerned to the main direction of civil engineering studying had not been cut short or briefed after the modification, while the theoretical teaching contents were combined with practical teaching contents to consolidate the engineering practice, and more relevant contents would be taught in the professional elective courses in the future.

\section{Contents of Practical TeAching}

The contents of practical teaching primarily served the main topics of theoretical teaching, and fully integrated and developed the resources of practical teaching with consideration of its objective circumstances. The Practical teaching contents were divided into the following topics.

\section{A. Investigation and survey to housing construction engineering}

In this part, the practical teaching would be carried out by on-site visiting to the classroom buildings, student dormitories and other buildings in the college. Study requirement: understand the main components of the frame structures, transmission path of mechanical load, judgment of major basis, the characteristics of structural materials, features and functions of buildings and analysis of quality problems on buildings.

\section{B. Investigation and survey to long span structures}

In this part, the practical teaching would be carried out by on-site visiting to the library, stadium and other buildings in the college. Study requirement: understand the types of longspan structures, the main composition of stress components in different forms, transmission path of mechanical load, judgment of major basis, the characteristics of structural materials, features and functions of buildings and other knowledge.

\section{Investigation and survey to road and bridge engineering}

In this part, the practical teaching would be carried out by on-site visiting to the roads, tunnels, bridges and other buildings in the college. The following contents should be grasped by the students through the visiting.

1) the concepts, characteristics and main types of the vertical and horizontal sections of roads, the side ditch, intercepting ditch, slope protection structures, retaining wall of roads.

2) composition, force-bearing characteristics and load transmission path of steel truss structure bridges.

3) composition, force-bearing characteristics and load transmission path of I-shaped bridges.

\section{Assignments of practical courses}

The assignments of practical courses should be designed carefully; theory should be linked with practice. The visiting and studying to the completed engineering would be helpful to the digestion and absorption of theoretical knowledge. The design of assignments focused on students' comprehensive understanding and application to the knowledge of the courses, as well as the ability of in-depth observation and thinking to the practice. The assignments needed to be finished in accordance with the students' subjective thinking and logical judgment, which were mainly used to develop students' dialectical thinking methods and self-learning ability, there was no sole criterion to their answers. Students needed to write a project research report after the Investigation and survey above mentioned was finished.

\section{REFORM OF THE TEACHING METHODS}

After the modification of the teaching contents and with the assistance of teaching methods reform, it would be easier to explain profound theories in simple language during the teaching process, provide more convenience to students who touched this major for the first time to help them to accept abstract knowledge content, establish professional basic knowledge preliminarily, provide them with clear and logical basic concepts and methods for engineering major studying, create professional ideas and methods to generate their strong aspiration to knowledge accordingly, build a dedication belief 
to their civil engineering career to make them study consciously and lively.

The following application attempts had been purposed for the teaching method in accordance with the actual objective circumstances.

\section{A. Application of flipped teaching mode[1]}

After certain of theoretical teaching class hours were completed, the teacher should assign after-class practical investigation and survey assignments to students in accordance with the actual circumstances, require them to study the contents of investigation and survey deeply; meanwhile, collect all kinds of relevant knowledge which was relevant to the classroom teaching content on internet. After full after-class studying, carry on in-depth discussion in classroom to achieve a certain degree of classroom clipped teaching.

\section{B. The improvement of traditional teaching mode}

Focused on "studying by student themselves" and advocated effective studying. In the classroom teaching, every teacher should focus on applying the new teaching philosophies in the actual teaching process, help students establish a correct view of studying, take investigative study as the principal, highlight their dominant position in studying and education, apply teaching, inspiring and discovering modes alternately in teaching process, carry out classroom teaching in the form of questioning and discussing. They should also focus on incentive teaching, arouse the thinking enthusiasm of students, fully respect each student, and give full play to the enthusiasm of independent studying to active the classroom atmosphere.

\section{Serve teaching with all kinds of social resources}

First of all, our department invited scholars and experts in civil engineering industry to give various lectures from time to time to expand the students' horizon and deliver them the latest information. For example: the department would give basic introductory lectures for freshmen every school year to match up the course teaching. Second, the department would make full use of various facilities in practice base to meet the teaching requirements of individualized teaching, extend the second classroom teaching, share resources of both parties, work together and carry out various forms of scientific research activities. For example: organized students to visit some construction sites; carried out various social investigation and survey activities. Good effectiveness had been obtained in practice teaching.

\section{Take advantage of multi-media technology[2]}

Make full use of the advantages of multi-media technology. Although the textbook- "Introduction to Civil Engineering" (The third edition) by Ye Zhiming presented the relevant contents in the area of civil engineering industry with new and student-oriented layouts and illustrations, but presentation with pictures only was a little bit monotonous and single. During the teaching process, with the application of multimedia teaching equipment, teachers could apply animation simulation, video, engineering simulation demonstrations and other means in the courseware production.
With the traditional classroom teaching and blackboard writing, it not only increased the amount of teaching information, enhanced the teaching effectiveness, but also increased the students' study interest.

\section{E. Serve the course teaching with network technology}

The College provided every teacher with a teaching file system, teachers could real-time update their courseware, upload teaching resources, answer questions online with this system. The college provided a network platform for excellent courses construction, students could receive the latest course teaching information through this platform, and it provided students with an independent study platform to improve their independent study ability. Meanwhile, teachers could share the latest information with students by collecting the latest information, uploading excellent courses to the platform or the teaching file system through the network.

\section{F. Make the second classroom play the role of practice teaching [3]}

Made full use of various types of buildings and structures in the college during the practical teaching process, determined the knowledge point of every building and structure visited by making standard visit route of practice teaching inside the college, then the theory could be linked with practice very well. If conditions permit, you can organize the students to visit the construction site near the school, so that students understand the knowledge involved in the construction process. The outdoor teaching was welcomed by the students very well, it solved the problem that some kinds of knowledge could hardly be described clearly in classroom, and the complementation of both methods ensured the teaching effectiveness greatly.

\section{INTEGRATION OF TEACHING RESOURCES}

Better course teaching purposes had been achieved by integrating the positioning of professional training goals with the goals of the course, other teaching resources and more elements integrated to the course made the teaching effectiveness of the course well affirmed, as shown in the example below: (1) Invited scholars and experts in civil engineering industry to give various special topic lectures from time to time to expand the students' horizon and deliver them the latest information in the industry; (2) Carried out practice teaching by making the under construction sites outside the college and completed engineering as the second classroom to assist the theoretical course teaching inside the classroom; (3)The comprehensive application of new teaching methods and means.

\section{CONCLUSION}

Introduction to Civil Engineering is an important and compulsory undergraduate professional course of Civil Engineering Major. The course has such characteristics as broad knowledge scopes, intensive enlightenment. It's important for the students to study it in order to understand the civil engineering industry, cultivate interest in learning, establish logical thinking mode, as well as lay a solid foundation for the future. 
Due to the decrease of class hours and the change of distribution ratio, the teaching content can't be completed in the new situation. The teaching goal can't be achieved, and the teaching effect is difficult to guarantee. Based on the experience of the construction of the provincial excellent course and the teaching experience for many years, we have deleted some content and reorganized the rest., and carried out the teaching in the form of special topic; At the same time, we try to use a variety of teaching methods and means to adapt to the changes in the structure of class hours.

The reform of the above teaching measures is conducive to achieve the purpose of teaching, improve the effectiveness of the teaching of the course, and meet the requirements of the training mode of application-oriented talents. And so it has been widely recognized by teachers and students. Such teaching reform is instructive for the training mode of application-oriented talents.

\section{ACKNOWLEDGMENT}

This work was supported by the education science "13th Five-year Plan" key topic of Fujian Province of China (The practice research of flipped classroom based on the microcourse, Project No. FJJKCGZ16-069).

\section{REFERENCES}

[1] Lai xiao. "Reform of "Excellent Engineer Education and Training Program" in "Introduction to Civil Engineering" in Combination with Micro Lesson,” Building Technology Development, Vol. 43, pp 160-161, September 2016.

[2] Zhang Xiao, and Wang Xi. "Research and Practice of Building Electrical and Intelligent Professional Introduction to Civil Engineering Course Teaching,” Journal of Jilin Jianzhu University, Vol. 32, pp 95-99, August 2015.

[3] Zheng Yuanxun, and Cai Yingchun. "Teaching reform of civil engineering introduction,” Journal of architectural education in institutions of higher learning, Vol. 21, pp. 62-65, January 2012. 